\title{
CREATIVITY AND IMAGINATION: SYMBOLISM, RITUAL PERFORMANCE AND IDENTITY FORMATION IN THE CORINTHIAN CHURCH OF SOUTH AFRICA ${ }^{1}$
}

\author{
Henry Mbaya \\ Department of Missiology \\ Stellenbosch University \\ Irvin G Chetty \\ Centre for Theology and Religion \\ University of Fort Hare
}

\begin{abstract}
In this article, we highlight the religious rituals that characterize the Corinthian Church of South Africa based in Durban in KwaZulu-Natal. We highlight that not only do these rituals express the unique identity of the members of the Corinthian Church but more importantly they act as tools through which the individual members strive to experience social/spiritual security. We also argue that more significantly the Corinthians use these rituals to reach out to their immediate communities. Thus through such activities the Corinthians contribute to the social cohesion of the local communities.
\end{abstract}

Key Words: Rituals, Community, Symbols, Spirit, Identity

\section{Introduction}

This study formed part of the National Research Foundation sponsored research project undertaken in the Eastern Cape at Phepheni, near Kokstad and Mlazi in Durban in the KwaZulu-Natal region in the years between 2007 and $2010 .^{2}$ In this paper, we outline the principal symbols and rituals that the Corinthian Church of South Africa based in Durban, uses in their worship, ceremonies and other expressions of spirituality. We try to define and describe what these symbols and rituals are. In particular, we seek to address the question: why are symbols and rituals important in the religious experience of the Corinthians? What social role do they play? What values do they foster? The fundamental argument of this paper is that symbols and rituals are the means by which the Corinthians access spiritual power. In their experience, this power associated with symbols and rituals, enhances their social security, and more importantly fosters values which promote care for the needy; consequently these factors contribute to the solidarity of communities. Another core question that this paper seeks to address is the role that rituals and symbols play in shaping

This article, in its earlier form, was read at Practical Theology Conference at the University of Pretoria, on 20 January, 2011. This final version is the joint effort of Dr Henry Mbaya and Prof Irvin Chetty.

2 The research was sponsored by the NRF under grant number 2054070. However, any opinions expressed or conclusions reached here are entirely of the authors and not of the sponsors. 
the identity of the Corinthian Church of South Africa? How do the rituals and symbols define the character and the life of the Corinthians and what value do they add to their life?

\section{Background}

The Corinthian Church of South Africa, founded in 1955 by Johannes Richmond, practices some elements of Ancient ritual cultic Hebraic traditions, employing Biblical imagery and symbolism and some elementary Islamic traditions. This is strongly embedded in an African ethos and cultural milieu. In this regard this church belongs to what early African scholars of African religious movements have traditionally categorised as 'Zionist' in contrast to 'Ethiopian' religious movements which are more political in orientation. ${ }^{3}$ According to these scholars traditionally the 'Zionist type' emerged largely in the late $19^{\text {th }}$ and early $20^{\text {th }}$ century to fill a vacuum left by the missionary churches. This vacuum was created by the non-accommodation of some important African traditions and cultural elements. These traditions and cultural elements used in African ceremonies and rituals, with the appropriate symbols, carry great meaning for the African.

\section{What does Identity entail?}

The question of identity is critical to the survival of individuals or groups. In her book, Who defines African Identity? Gerrie ter Haar confirms Charles Taylor's thesis assets that the identity of African religious communities in the Netherlands tends to be influenced by white communities tending to assert their differences over the Africans, and the public insistence that the Africans develop their identity apart from the whites. ${ }^{4}$ Borrowing Charles Taylor's term 'misrecognition' as a notion that influences identity, Ter Haar asserts that the identity of Africans in the Netherlands is shaped by the whites' misrecognition of blacks. In this respect, Ter Haar implies that identity is two-fold in character, where a group relates to the 'other' and vice versa. Therefore, identity is about representation. As Ter Haar argues, the question of identity should involve negotiation by the people concerned and that in the Netherlands for Africans it is an issue which entails their personal security and the inner strength. ${ }^{5}$

On the other hand, Michel Pollak asserts that identity is "... the image that a person acquires along life regarding herself, the image that she builds and presents to the other ones and to herself, to believe in her own representation, but also to be noticed in the way as she wants to be noticed by others." Identity therefore entails defining who and what one is always in relation to the other. It has to do with what distinguishes one from the other; what makes one unique from the other, separating oneself from the other.

It also entails affirmation of one's special characteristics that separates one group from the other. More importantly, it is about defining one's role over the other. Hence by implication, the assertion of one's identity entails the assertion of a degree of power by a

David Barret, Schism and Renewal in Africa, Nairobi, Addis Ababa, Lusaka: Oxford University Press, 1968; Martin West, Bishops and Prophets in a Black City, Cape Town: David Philips, 1975.

4 Ter Haar, G, "Who defines African Identity?" in James L Cox and Gerrie Ter Haar (eds.), Uniquely African? African Identity from Cultural and Historical Perspectives, Asmara: Africa World Press, 2003, Chapter 12. Ibid.

6 Pollak, M (1992). Memoria e identidade social in Estudos Historicos, n. 10 cited by Alice Beatriz da Silva Gordo Lang, Reconstructed Identity; Portuguese Immigrants in Brazil in Philippe Denis and James Worthington (eds.). The Power of Oral History, Memory, Healing and Development, XII International Oral History Conference XII, Pietermaritzburg, South Africa, 24-27 June, 2002, Volume 2, p. 941. 
group over the others, which is not always articulated but rather is implied in symbols and rituals.

For the Corinthians the question of identity is intrinsically intertwined with their performance of rituals and religious symbols, and how these distinguish them from the other religious groups - more importantly, how their identity generates value systems amongst themselves and its impact on the communities. As will be shown below, the performance of religious symbol emits authority and by implication, power.

\section{Sources of Identity}

The members of the Corinthian Church of South Africa derive their religious identity from three main sources which have evolved from the ministry of their legendary founder, Johannes Richmond who was based in Durban. ${ }^{7}$ Firstly, the Corinthians use extensive Biblical imagery, rituals, and motifs. Secondly they have adopted elementary Islamic elements. Finally these include African traditional religious and cultural elements. ${ }^{8}$ There are also some elements of Hindu religion. These sources appear to have blended reasonably well.

\section{The Spirit - the Bedrock of Spirituality}

In their religious practice it becomes evident that the Corinthians consider these Hebraic, Islamic and African elements as operating directly under the influence of the Spirit. In their view, symbolism and performance of ritual directly relates to the spirit world. ${ }^{9}$ It is the Spirit that animates worship steeped in traditional African ethos. Similarly, it is the Spirit that fosters worship characterised by semi-Islamic customs. Thus the Spirit is the cause and force that defines the Corinthian's relationship with nearly every aspect of their life and outlook on life. Worship is essentially a quest for spiritual experience. Performance of ritual facilitates spiritual experience; it unlocks the mysterious, powerful world of the Spirit.

These elements convey powerful symbolic meanings which appeal emotionally, intellectually and spiritually to the Corinthians. In this regard their identity is immersed in religious symbols and rituals which communicate to a deeper world of the Spirit(s) to which they relate. A definition of symbols and how they link with rituals and how these shape the life of the Corinthians is necessary to advance our discussions.

\section{What is a symbol?}

Richard Woods defines a symbol as "the power to represent the world cognitively and aesthetically, especially through visualisation." ${ }^{10}$ In particular, it "invests objects or actions with an inner meaning expressing Christian ideas... it appeals to both intellect and the

Following his calling experience, Johannes Richmond became a charismatic figure renowned for his healing ministry for various needs, notably barren women, and care for the neglected blind in the streets of Durban. Through a large following, he subsequently founded the present Corinthian Church in Durban in 1955. Richmond's mother was a Zulu while his father was an Indian with an Islamic background.

8 Some Islamic elements include men wearing a beard and a fez and members of the congregation enter the church without shoes. This latter practice is also common to Hindus.

9 Interview with Xolani Zondi, Nosipho Mfenqa and Wellington P Dingani, Kokstad, 18/07/09.

10 Woods, R 'Article entitled: 'Religious Symbols and Spiritualiy in an Electronic Age' http://www.jstor.org/pss/1199815, p. 2, accessed 10 November 2010. 
emotions." 11 Thus symbols operate on the level of imagination and perception - engaging mental faculties, and visualisation and conveying meaning through objects or ideas. Through symbols or ritual people transcend into the realm of spiritual meanings.

However, beyond mental engagement, symbols transmit an emotional and spiritual experience, giving the individual or groups involved a touch of the 'Other' reality. Woods further states that "symbols participate in the transcendence of spirit, opening onto a dimension of reality beyond themselves and us while retaining their connection to the world of everyday experience". ${ }^{12}$ More importantly, symbols "create a resonant mythos expressing the moral values of the society or the teachings of the religion, foster solidarity among adherents, and bring adherents closer to their object of worship." ${ }^{13}$ Thus symbols and rituals facilitate a religious encounter with the adherent.

More importantly, Woods asserted that symbolism is the vehicle through which the adherents seek "...to comprehend and integrate the transcendent and often elusive parts of life into the whole..." In other words, it is the 'imaginative power' which seeks to "to shape the contours and direction of the flow of experience." 14 Thus in his view, the potency in symbolism lies in its power to convey creatively the transcendent experience and channel it. Thus Christian symbolism invests objects and actions with an inner meaning expressing Christian ideas.

\section{Where do Symbols and Ritual Interface?}

As a concept ritual has been much discussed. ${ }^{15}$ In this context, however, the concept will be used broadly to include ritual as a vehicle of communication, speech and bodily language "as well as the language of material symbols." ${ }^{16}$ From the perspective of African scholars and the African context, interpretations of the concept entail something transcendental and mystical; "the transcendental is actual and ... the sacred is ordinary in the African world."17 Or as Cas Wepener asserts, rituals are "symbolic actions that are always interactive and corporeal, sometimes accompanied by texts and formulas, aimed at the transfer of values in the individual or the group, and of which the form and content are always culture, context and time bound, so that the movement in the reality which is presented in the rituals remains dynamic." 18

Thus whereas symbols convey religious meanings or ideas by evoking emotional experience, performance of rituals seeks to create a religious experience immersed in symbols. On various levels both seek to construe a world of reality in which the participants seek to engage. They are the lenses through which people see reality and relate to it, more significantly they tend to influence the conduct of individuals. Both carry meaning and values of life.

\footnotetext{
http//www.theosociety.org: accessed 08/09/11.

Ibid.

http//.www.theosociety.org: accessed 08/09/11.

http://www.jstor.org/pss/1199815, accessed 10 November 2010.

5 See Cas Wepener, Ignatius Swart, Gerrie ter Haar, Marcel Barnard, 'The Role of Religious Ritual in Social capital Formation For Poverty Alleviation and Social Capital Development: Theoretical and Methodological Points of Departure of A South African Exploration in progress' (Draft paper for conference, (?) p. 5.

Ibid.

Ibid.

18 Cas Wepener, From Fast to Feast, a ritual-liturgical exploration of reconciliation in South Africa Cultural contexts based on DTh Thesis, Van Vas tot Fees, 'n Ritueel-liturgiese Ondersoek na Versoek na Versoening binne Suid-Afrikaanse Kultuurkontekste (2004), Stellenbosch University, p. 27.
} 


\section{Symbol/Ritual and Spiritual Power}

The Corinthians ascribe symbols and rituals with what Johan Cilliers calls force vitale, the all-pervasive power, a force in the cosmic order that penetrates all reality; ${ }^{19}$ this power can be manipulated by individuals for good or for evil. ${ }^{20}$ In other words, for the Corinthians the symbols derive their ability from the realm of Spiritual power, they are vehicles which foster power, through which power, Amandla flows. To the Corinthians this power manifests itself in the form of Spiritual authority, which they seek to tap and wield. ${ }^{21}$ Thus to enter into communion with this power, the Corinthians employ symbols and perform rituals to achieve their fundamental goal which is spiritual activity. ${ }^{22}$

The power of the symbol lies in its ability to construe a social reality, that is to project and convey a world view that relates natural phenomena or incidents/accidents to the influence of the spiritual world. As we will illustrate below such symbols operate on the level of imagination since, though concrete by nature, they nevertheless convey abstract ideas. Thus symbolism and ritual are the means by which the power of the Spiritual world is unlocked and made available to its adherents. In their perceptions the Corinthians directly link spiritual power with rituals and symbols. ${ }^{23}$

\section{Why 'Corinthian' Church?}

Symbolically the name 'Corinthian' is significant. It is associated with Pauline ministry to the Corinthian Church of Asia Minor which occupied a central role in the ministry of Paul. Tradition has it that it was the first place where the believers came to be known as 'Christians.' More significantly, the spiritual phenomena that characterised that church, its spiritual richness, seemed to appeal to the Corinthian Church. They appear to see themselves as the heirs of the Corinthian Church associated with Paul. In choosing this name the Corinthians see themselves as spiritually connected to the historic church of Asia Minor and as representing that church. Thus the name Corinthian carries a powerful symbolic message.

\section{Four Dimensions of Symbols and Rituals}

Symbols and rituals function on four levels in the Corinthian Church namely:

\section{For Re-Integration/Binding/Fellowship (Wholeness/Healing)}

The first category involves those that seek to enhance 'wholeness' (reintegration) of a human personality or of individuals into a group. Operating from the worldview that life is essentially spiritual, that harmony of the spiritual and material order is fundamental for the survival of a person, and that evil forces destabilize this union, the Corinthians consider achieving 'wholeness' of personality or groups of 'individuals' as fundamental to human

19 Cilliers, J Worshipping in the Townships - A Case Study For Liminal Liturgy?, p. 76.; see also G ter Haar, Religion and Social Development, summary notes of her presentation at the second research workshop on Religion and Social Capital Formation, at the Theological Faculty of Stellenbosch University, 03/02/09, p. 2. Cf. Klaus Nürnberger, 'Ancestor Veneration in the Church of Christ?' in the Journal of Theology for Southern Africa, 129, November 2007, p. 62.

$22 \quad$ Ibid. p. 77.

23 Interview with Reverend WP Dingani, Kokstad, 04/12/10. 
survival. ${ }^{24}$ It is for this reason that the Corinthians use religious symbols and perform rituals to bring about wholeness in the form of healing or well-being or the seeking of blessings for personal prosperity.

\section{Fellowship with the Founder/Ancestors/Spirit}

At the start of every service, a prayer is said over food items, inter alia, oranges, apples, or biscuits $^{25}$ which are placed on a table where seven candles are lit. The name of the Founder/Spirit (and the Angel) is invoked. It is believed that the congregation enters into fellowship with the Angel/Founder/Spirit. From this point, until the end of the service the Corinthians believe that they are in fellowship with the spirit of the Founder. The food symbolically represents his presence and it is this presence that the Corinthians believe mystically links them with God, Jesus Christ and the Holy Spirit. Gerrie Ter Haar noted that fellowship with the Spirit constitutes the most important feature of the African Initiated. However, the association of food and fruits with the Spirit is characteristic of the Hindu religion. ${ }^{26}$ Noticeable here is the Indian background of the Founder. In observing this particular ritual, it would seem that the Corinthians distinguish themselves from the other churches that fall in the category of the Initiated Church Churches in Southern Africa.

\section{Roundhouse/Rondavel}

At Phepheni, worship is regulated and determined by the round shape of the church (house/building). Large part of worship involves 'running' clockwise in circles for four or five, or six hours. Circular rather than rectangular buildings seem to suit their manner of worship. This contrasts sharply with the rectangular church buildings of the 'mainline' churches of Roman Catholic, Anglican, Presbyterian, Methodist or Dutch Reformed denominations. Their fixed pews do not allow for free movement which is possible at Phepheni and other Corinthian congregations. Symbolically, a circular space traditionally provides for intense corporate worship, interaction with the ancestors, and also promotes intimacy and fellowship. Everyone is an actor, on the same level with one another. ${ }^{27}$ It also explains why these people seem to be physically fit. Furthermore according to Reverend Dingani dancing/running (worship) enhances the descent of and fellowship with the (Holy) Spirit. ${ }^{28}$

\section{Handing over the Staff: Symbolic Transmission of Leadership Authority}

During the annual function held at Mlazi, at a certain stage during worship, a pointed staff that the Founder used is handed over by a bishop to the wife of the Founder, Mrs Bestina Richmond. In this respect, symbolically, fellowship with the Founder is established. From that stage Mrs Bestina Richmond assumes the ceremonial role of a president. The staff is

24 Cf. Johan Cilliers, 'Worshipping in the Townships - A Case Study for Liminal Liturgy?' in Journal of Theology For Southern Africa, November, 2009, No. 132, 75. See also V Molobi, 2009. 'Vanguard of Africa culture: an analysis of the oral history of selected AICs in Tshwane (Pretoria)'. Studia Historiae, 2009, vol. xxxv. (1), p. 96.

25 This practice is surprisingly similar to certain groupings of Sanathanist Hindus, even in South Africa.

26 See Maxwell, Diesel \& Naidoo, 'Hinduism in South Africa' in Living Faiths in South Africa, (eds.) M Prozesky \& J de Gruchy, David Philip, Cape Town, 1995:182-187.

27 Circular as opposed to rectangular is consistent with African worldview where the ancestors are at the centre of family life and fellowship, where members of the family relate to each other on the same level.

28 The same idea was expressed by a member of the Bantu Bethlehem Christian Apostolic Church of South Africa, see Martin West, Bishops and Prophets in a Black City, 93. 
the symbol of authority that is ritually handed over to the Founder's wife. The Corinthians attribute spiritual power to the Founder, Johannes Richmond who they believe operates with the Spirit (of God) and Jesus. ${ }^{29}$ Hence the prophetic spirit emanates from this realm. However, following the example of the Founder, men and boys also carry staffs (sticks). These sticks are said to possess spiritual power to ward off evil powers. ${ }^{30}$

\section{Candle Light}

A lit candle plays a very important role in the ritual of the Corinthian Church. It is associated with the Spirit. The colour of the candle is symbolically significant; a burning white candle is associated with the Spirit (of God) and the Angel while candles in assorted colours are associated with the ancestors. In both cases a lit candle serves as part of a ritual to enhance invocation of the Spirit.

Three white lit candles representing the Trinity or signifying completeness are used at an ordinary Sunday service. Seven are lit for the bigger occasions such as the ritual ceremony of the sacrifice of the red heifer. However, a lit white candle carries a double meaning: these are to repel the forces of darkness of evil (Spirits) inhabiting a place or possessing a person, and also to invoke the spirit of the Founder/angel/spirit (and in some cases of the ancestors). ${ }^{31}$

As an example of the former, a person visiting the congregation for the first time at worship is instructed to carry a lit candle in a procession as $\mathrm{s} / \mathrm{he}$ is led into the place of worship. ${ }^{32}$ In each case the ultimate goal is to effect reintegration of the individual into the congregation of worshippers through ritual.

\section{Water - a Symbol of Life and a Ritual Cleansing Object}

\section{Incense for Purification/Cleansing}

Water carries important symbolic significance. It is used for baptism, as a purifying ritual, cleansing from sin. It is also used to sprinkle on worshippers as a form of blessing, as protective warding off bad spirits. It is also regarded as having a healing element which empowers life. Similarly, burning incense (impepo) at the start, end, or during the course of the service induce the descent of the Spirit but also like water, incense serves to purify or cleanse the space or the person. ${ }^{33}$ Sprinkling of holy water, with a pungent smell of incense in the context of vigorous worship, music and dance charge the atmosphere with a higher level of emotion, creating a sense of awe and mystery, which is powerful to the senses. This seems to bind the worshippers magically together. ${ }^{34}$ In this context, at least for a while, social distinctions among the worshippers disappear, as rituals unite the worshippers into a cohesive unit.

\footnotetext{
29 Interview with WP Dingani, Kokstad, Zibuthe, Kokstad, Bestina and Jean Richmond, Wyberg, Durban.

30 Interview with Reverend WP Dingani, Kokstad, 17/12/10.

31 Interview with Xolani Zondi, Kokstad, 24/09/10.

32 The author went through this ritual four years ago at Phepheni, similarly some members of the project and visitors from Germany, the Netherlands and Cape Town experienced this in February 2010 when they visited the Corinthian congregation at Phepheni.

33 See Henry Mbaya, 'The role of ritual in shaping the life of the members of the Corinthian Church of South Africa at Phepheni, near Kokstad: from the perspective of social capital,' a paper presented at the Social Capital Conference at Communitas, Buvton, Stellenbosch University, Stellenbosch, 25/06/09.

34 Cf. Johan Cilliers, Worship in the Townships - A Case Study for Liminal Liturgy? in Journal of Theology for Southern Africa, p. 76.
} 


\section{The Influence of a 'Prophetic' Word}

\section{Symbolic Communication through Dreams and Visions}

\section{Wellness/Health}

In the Corinthian Church as is the case with other African Independent Churches, worship is essentially an act of fellowship with the spirit world of the Founder/ancestors and Jesus/God and the experience of spiritual power, ${ }^{35}$ which on occasions leads to spirit possession of the individual. ${ }^{36}$ Power is accessed through communication with the spirit world. In most cases the spirit communicates symbolically to the individuals, especially in the form of dreams or visions. ${ }^{37}$ For instance, when Cas Wepener visited Phepheni congregation, a middle-aged woman had a vision of a white horse that had arrived at the church before coming to church. ${ }^{38}$ A prophetic ('spiritual') word prescribes the colours of the attire that the individual must wear appropriate to their health or spiritual condition. For instance, a prophetic word may prescribe blue attire with the star and moon inscribed on it.

\section{Uniform Attire}

Except for special occasions such as isitshisa when they all wear golden colours and for Guild Days (umanyano days) such as 25 December when they wear white 'tops' with a green 'bottom,' their basic religious attire on Sundays is a white cassock-like tunic, they call umnazarete. ${ }^{39}$ According to Reverend Wellington Dingani, white symbolizes angels, 'purity' and 'holiness. ${ }^{40}$ Hence they are exhorted to become holy (or innocent) like the angels. ${ }^{41}$ For the Corinthians this attire helps to forge a common identity by diminishing socio-economic distinctions that prevail among them. In this attire the members feel a stronger sense of belonging together as a 'family' at least for a while. This 'family feeling' has ethical dimensions, as they feel the need to assist one another when in need at least for a while. This 'family' feeling tends to obliterate the distinctions between poor and rich, instilling in them a common purpose - that of serving humanity.

\section{Baptism}

Ritual objects appear to define and determine the efficacy of baptism. A one-Rand coin thrown into a glass of water signifies the permanence of baptism as the coin is compared to a star, implying that Baptism must always shine like a star. ${ }^{42}$ The parent of a child to be baptised presents two chickens, one indigenous and the other hybrid. While the latter is

35 Interview with Reverend Wellington Dingani, Bishop Zibuthe, Kokstad, 12/12/10; Cf. J. Cilliers, 'Worshipping in the Townships 'A Case Study for Liminal Liturgy?' in Journal of Theology For Southern Africa, November, 2008, No. 132 - p. 76-77.

36 Cf. Ter Haar, G Religion and Social Development, summary notes of her presentation at the second research workshop on Religion and Social Capital Formation, at the Theological Faculty of Stellenbosch University, 03/02/09., p. 2.

37 Ibid.

38 Cas Wepener is the co-ordinator of this project sponsored by the National Research Foundation. Besides previous visits, he also visited the Phepheni congregation this year.

39 Interview with Reverend Wellington Dingani, Kokstad, 17/12/10.

40 Same interview.

41 Same interview.

42 See Henry Mbaya, 'The role of ritual in shaping the life of the members of the Corinthian Church of South Africa at Phepheni, near Kokstad: from the perspective of social capital,' a paper presented at the Social Capital Conference at Communitas, Buvton, Stellenbosch University, Stellenbosch, 25/06/09, p. 6. 
slaughtered the indigenous is raised by the minister. They believe that the growth and development of the baptised depends on the life of the indigenous chicken. ${ }^{43}$

More significantly, as part of preparation for Baptism and long after, a parent has the obligation to read regularly a portion of Scripture to the child. On the day of Baptism, the wife of the minister questions the parent to determine whether the parent has been doing this properly. As a result people develop skills in public reading, and teaching of Scripture and oratory. This is what Nancy Ammerman calls "'civic capital', abilities and connections for political life." 44

\section{Lord's Supper}

Ironically, the Lord's Supper, a ritual that is supposed to be inclusive, tends to be exclusive, as only those 'worthy' are challenged to come forward at Phepheni. In this way, the ritual tends to entrench exclusion rather than inclusion. ${ }^{45}$

\section{Funeral Cleansing/Purification Rituals}

Water and Blood

Believing that death disconnects a person from wholeness of life on earth, the Corinthians perform rituals that seek to reintegrate the members returning from funeral ceremonies in the congregation. They are spattered with a mixture of blood and the gall bladder of a goat the vicinity of the church. ${ }^{46}$ In this way the members are once more reintegrated into the congregation. The belief is that the cleansing ritual breaks down the mystical union with the 'spirit' of death, so, according to the minister of Phepheni, Reverend Wellington Dingani, his members tend to enjoy longer life than the others.

Gerard Lukken has argued for the ethical dimension of rituals,${ }^{47}$ that rituals influence our ethical behaviour. ${ }^{48}$ Prohibition of eating at the funeral ceremonies serves to avoid fellowship or contact with the 'spirit' of death. On the other hand, by abstaining from funeral festivities, the Corinthians are critical of the huge expenses associated with the funeral feasts of today. ${ }^{49}$ They encourage simplicity.

$43 \quad$ Ibid., p. 9.

44 Nancy Ammerman, 1997. Congregation and Community. New Brunswick/New Jersey/London: Rutgers University Press, p. 364 cited by Henry Mbaya, 'The role of ritual in shaping the life of the members of the Corinthian Church of South Africa at Phepheni, near Kokstad: from the perspective of social capital,' a paper presented at the Social Capital Conference at Communitas, Buvton, Stellenbosch University, Stellenbosch, 25/06/09, p. 9.

45 Henry Mbaya 'The role of ritual in shaping the life of the members of the Corinthian Church of South Africa at Phepheni, near Kokstad: from the perspective of social capital,' p. 9.

46 Ibid., p. 8.

47 Cas Wepener, From Fast to Feast, a ritual-liturgical exploration of reconciliation in South Africa Cultural contexts, p. 125.

48 Ibid.

49 Interview with Reverend WP Dingani and Xolani Zondi, Kokstad, 05/01/11. 


\section{'Isitshisa' - A Ritual of 'Offering'}

Animal sacrifice clearly distinguishes the Corinthians from many other AIC's. ${ }^{50}$ It is performed for various reasons, notable among them to enhance health and to ward off danger. ${ }^{51}$ However, special mention should be made of the sacrifice of the red heifer, commonly known as isitshisa precisely because of its parallels with the sacrificial cult of the Old Testament in the Book of Leviticus and the traditional African sacrifices to the ancestors. It is held every last day in October at Mlazi, south of Durban. The ritual sacrifice of a red heifer is highly symbolic and dramatic. ${ }^{52}$ At about midnight or thereafter, processed in by worshippers, the red heifer is sprinkled with holy water, incensed, and a prayer said, then processed out. The heifer is then slaughtered and offered as a burnt sacrifice.

In the view of the Corinthians, wearing the golden attire for the occasion mystically connects the Corinthians to the sacrifice of the red ('golden') heifer, hence they perceive themselves as a 'sacrifice' in the service of God to the blind and the needy in the community. ${ }^{53}$ Sermons during the ceremony exhort the Corinthians to 'offer' themselves in the service of love and friendship to the blind and the needy ${ }^{54}$ The golden colour symbolically implies brightness or light, hence blessings. ${ }^{55}$

The blood of the heifer which is shed is 'life' which symbolically becomes available to them, through the ashes. It is for this reason that the Corinthians offer prayers for barrenness, and employment. These prayers, according to Wellington Dingani, Jean and Bestina Richmond are answered. ${ }^{56}$ Paul Ricoeur's assertion that a "symbol is the power to discover and reveal the bond between human persons and what they consider to be sacred" particularly applies to the socio-religious dimension of the Corinthian's annual ritual sacrifice of a red heifer. The rituals performed by the Corinthians generate spiritual 'power' which engenders values which ultimately impact on the relationships.

Enacted every year on the same day, at the same place, more or less at the same time, the Corinthians feel spiritually and socially renewed and 'empowered' as a 'chosen' people by the Founder mystically bound together, through fellowship of worship and partaking in the feast. After worship they are bound together, new friendships are forged and old ones renewed. ${ }^{57}$ To ensure that more attend the following year, the members are encouraged to share their experience with those that did not attend. Thus "symbols help...create moral values of the society or the teachings of religion, foster solidarity among adherents closer to

Even though other African Initiated Churches perform animal sacrifices, it is the Corinthian Church of South Africa that seems to perform this ritual more regularly. In his studies Martin West also noted this feature, see Bishops and Prophets in a Black City, p. 180-184, 185-187.

51 Interview with Xolani Zondi, Kokstad, 18/10/09; with Reverend Wellington P Dingani, Kokstad, 17/12/10.

52 At midnight, the red heifer is ceremoniously led into the church by the crowds of worshippers. Then a prayer is offered, incense (impepo) burnt over it and aspersed with holy water.

53 Mbaya, H, 'The Socio-practical implications of Isitshisa in the Corinthian Church of South Africa', a paper presented at Stellenbosch University's Poverty and Social Development Conference held at Holy Trinity Anglican Church hall, Kokstad, 19-21 February 2010 and subsequently published in the Journal of Practical Theology, (HTS), Teologiese Studies/Theological Studies 67 (2), Art.\#930, 8 pages.

Doi: $10.4102 /$ hts.v67i2.930. Ibid.

55 Ibid.

56 Interview with Mrs Bestina Richmond, Jean Richmond and Reverend Wellington Dingani, Wyberg, Durban, 04/01/10.

57 Interview with Xolani Zondi, Mlazi, 31/10/09; Mrs Bestina, Miss Jean Richmond, Wyberg, Durban, $04 / 01 / 2010$ 
their object of worship." 58 In the words of Xolani Zondi, "the Isitshisa generates 'spiritual' power which translates into social action, notably helping other people like the blind and others who may stand in need, in the community." ${ }^{, 59}$

Gerrie ter Haar noted that spiritual power "is also transformative," it leads to "selfempowerment in the process of development. ${ }^{\prime 60}$ For most of the Corinthians the sacrifice is an experience of the spirit that renews their life as individuals but also the life in the community - it inspires them to emulate the value of the charity shown by the Founder towards the needy. ${ }^{61}$ It is their annual outreach to the blind and the needy in general that distinguishes them from other faith groups. They consider their responsibility to the blind as a sacred obligation bequeathed to them by their Founder.

Here, parallels exist with the Ancient Israelites who, by painting the blood of a lamb on the door posts of their homes, protected themselves from the angel of death in Egypt prior to the Exodus. Yet the idea of sacrifice is also very much African, as sacrifices are offered to the Ancestors. The belief that certain objects can be endowed with mystical power to ward off evil is also African.

\section{As a Deterrent against Evil Spiritual Forces}

The link between symbol and ritual performance and spirituality occurs on the mental, psychological, intellectual or emotional levels. Richard Woods puts it as follows, "Symbol and myth [are] the concrete elements of spirituality [they] are themselves constructions of the human spirit, specifically of our imagination" ${ }^{62}$ Upon the instructions of their Founder, the Corinthians wear red ribbons or red attire, which in their belief will protect them from malevolent spirits, hence ritual objects such as red ribbons and golden chains are popular. ${ }^{63}$ A similar notion was expressed by the members of the Bantu Bethlehem Christian Apostolic Church during the research conducted by Martin West in 1975, in connection with healing of the sick. ${ }^{64}$

Thus, it is held that a kind of mystical relationship exists between symbolic ritual objects and the spiritual realm, the reservoir of spiritual power. To the Corinthians wearing such objects draws some spiritual power which serves to deter evil from occurring in the life of an individual such as bloodshed in the form of accident, murder, or abuse of women and children such as rape. ${ }^{65}$ These are vehicles of power - power to protect the vulnerable in the society. In this respect, people are "reminded of their human dignity, often in the face of a society that structurally proposed and actively enforced the diametrically opposite."

In this respect these ritual objects operate on the level of creative imagination, projecting a reality, where red colour relates to danger which must be warded off by equally

\footnotetext{
58 http//.www.theosociety.org: accessed 10 November 2010.

59 Interview with Xolani Zondi, Kokstad, 08/12/10.

60 Gerrie ter Haar, Religion and Social Development, summary notes of her presentation at the second research workshop on Religion and Social Capital Formation at the Theological Faculty of Stellensboch University, 03/02/09.

61 Interview with Mrs Mfenqa, Xolani Zondi and Reverend Wellington P Dingani, Kokstad, 08/12/10.

62 Woods, R, 'Religious Symbol and Spirituality in an Electronic Age', 2: http://www.jstor.org/pss/1199815, accessed 10 November 2010.

63 Interview with Reverend WP Dingani, Kokstad.

64 West, Bishops and Prophets in a Black City, p. 117.

65 Interview with Bishop Zibuthe, Reverend WP Dingani, Kokstad, 15/08/10.

66 Cilliers, J 'Worshipping in the Townships - A Case Study for Liminal Liturgy?' in Journal of Theology for Southern Africa, November, 2008:77.
} 
powerful ritual objects such as red attire or a chain. Red is a colour that symbolically has a double meaning: negative and positive. Negatively, it is associated with 'danger,' bloodshed in the form of accident of any sort, murder or abuse such as rape, in a society where violence seems to have been naturalized. Thus, red associated with bloodshed is visualized as a colour depicting danger from which the 'blood of the lamb' and the Lion of Judah will protect them. ${ }^{67}$ Firstly, through a prophetic word, red depicts a scenario of healing or wellness. Secondly, red is also considered as a deterrent against malevolent forces, such as accidents caused by evil forces, or anti-social behaviour such as crime, rape, and murder. ${ }^{68}$

\section{For Enhancing Faith Values}

Thirdly, activities such as preaching and teaching enhance the formation of faith values. Sermons during worship service such as isitshisa or any Sunday service foster the spirit of love and care for the blind and other needy. ${ }^{69}$ In caring for the blind the Founder is portrayed as a model of Christian life. This is stressed by using Jesus' examples of caring for the needy. The Corinthians particularly stress perseverance as a virtue in their relationship with others. They are exhorted to persevere in caring for others. The idea of giving themselves symbolically as a sacrifice during the isitshisa is promoted. Blood symbolizes God's 'gift' of life to the people associated with the biblical narrative of the Exodus where the blood of the lamb carried salvific effect. The idea is that the initiates receive life from God so that they in turn will dispense it for the salvation of others. Then finally there are those that relate to initiation.

\section{Relating to Rites of Initiation - an Evangelist, Deacon and Minister}

Smearing goat's blood, fat and special oil on the face of the person in the process of becoming an evangelist or deacon or a minister are an important ritual for the initiates. ${ }^{70}$ On this occasion stress is laid on the 'sacrificial' (death) offering of the goat by which those to be made evangelists, deacons or ministers are likewise exhorted to 'offer' themselves like a goat in service to God and their neighbours. ${ }^{71}$

\section{Islamic Features}

Another striking feature that distinguishes the Corinthians from the other African Initiated Churches is their observation of some Islamic traditions. Following their Founder, who had an Islamic background, ${ }^{72}$ the Corinthians adhere to some Islamic traditions, notably men wearing a beard and a fez; shoes are not worn during worship service, as the place of worship is regarded a holy ground. It would appear that they hold elements of both

67 Interview with Bishop Zibuthe, Reverend WP Dingani, Kokstad, 15/08/10.

68 Interview with Reverend Wellington P Dingani, Kokstad, 04/11/10.

69 See Henry Mbaya, 'The Socio-practical dimension of isitshisa in the Corinthian Church of South Africa', a Paper presented at the International Conference on Poverty and Social development held at Holy Trinity Anglican Church hall, Kokstad, South Africa, 19-21 February 2010, p.

70 Henry Mbaya, 'The Socio-practical implications of isitshisa in the Corinthian Church of South Africa' a paper presented at Stellenbosch University's Poverty and Social Development Conference held at Holy Trinity Anglican Church hall, Kokstad, 19-21 February 2010, p. 6.

71 Same interview.

72 According to the Founder's wife, Mrs Bestina Richmond, her husband had a Zulu mother and an Indian father. 
Christianity and Islamic customs together without tension. Furthermore, a resemblance to ritualistic Hinduism was also found in the 'offerings' to god.

\section{Hindu Elements}

Earlier on we commented on the similarities between the offering of food items (oranges, apples or biscuits) and invoking the Spirit of the Founder of the Corinthian Church and certain groupings of Hindus in South Africa. This strand of Hinduism could be best regarded as Sanathanist Hinduism. ${ }^{73}$ This stream of Hinduism focuses on practical or ritualistic aspects rather than the philosophical and doctrinal ones. As a part of Hindu puja (devotional and ritual worship) worshippers bring offerings of fruit, coconuts, milk and incense on a tray to the Hindu Temple. Camphor is also burnt. The priest conveys a blessing by marking the forehead of the devotees with ash from the incense or camphor. Devotees of the Hare Krishna Movement observe this ritual daily at the Krishna Consciousness Temple in Durban. ${ }^{74}$

\section{Conclusion}

In light of what we have discussed, it becomes apparent that the Corinthians have assimilated some religious imagery, myths, symbols and signs of the Old Testament cultic ritual performances. Some of the influences have also come from Hinduism and Islam. Through years of teaching and practice these aspects have been internalised, and consequently have become embedded in their subconscious. Moreover, when faced with challenges relating to health or security, it seems almost natural that the Corinthians respond within this mental framework. In other words, in symbols and rituals spiritual power is implicated. This is the focus of the Corinthian's experience. Rituals and symbols give the Corinthians a measure of identity that seems to transcend social differences amongst them. More importantly, these rituals and symbols channel their energy in social engagement. Intense common loyalty to tradition of the Founder and intense, regular worship seem to influence social cohesion. This is reinforced by the African culture, ethos and tradition which promote even greater social cohesion. Ritual is the hub of worship and life of the Corinthian community. It is the glue that binds the people together, promoting the common values of charity to the blind, concern and care for one another and the needy. The net result is that a deep degree of trust and co-operation is generated among the Corinthians.

\footnotetext{
73 See Maxwell, Diesel and Naidoo, Hinduism in South Africa' in Living Faiths in South Africa, (eds.) M Prozesky \& J de Gruchy, David Philip, Cape Town, 1995:182-187.

74 This practice has been particularly observed by one of the researchers of this article.
} 


\section{BIBLIOGRAPHY}

Barret, D 1968. Schism and Renewal in Africa, Nairobi, Addis Baba, Lusaka: Oxford University Press.

Cilliers, J 2008. 'Worshipping in the Townships - A Case Study for Liminal Liturgy?' Journal of Theology for Southern Africa.

Cox, JL \& Ter Haar, G (eds.) 2003. Uniquely African? African Identity from Cultural and Historical Perspectives, Asmara: Africa World Press.

Mbaya 2009. 'The role of ritual in shaping the life of the members of the Corinthian Church of South Africa at Phepheni, near Kokstad: from the perspective of social capital,' a paper presented at Social Capital Conference at Communitas, Buvton, University of Stellenbosch, Cape Town, 25/06/09.

Mbaya, H 2010. The socio-practical implications of isitshisa in the Corinthian Church of South Africa' a Paper presented at University of Stellenbosch poverty and social development Conference held at Holy Trinity Anglican Church hall, Kokstad, 19-21 February, 2010.

Molobi, V 2009. 'Vanguard of Africa culture: an analysis of the oral history of selected AICs in Tshwane (Pretoria)' Studia Historiae, 2009, vol. xxxv. Nor. 1.

Nürnberger, K 2007. 'Ancestor Veneration in the Church of Christ?' in the Journal of Theology for Southern Africa, 129.

Prozesky M \& J de Gruchy (eds.) 1995. Living Faiths in South Africa. Cape Town: David Philip Publishers.

Wepener, C 2004. From Fast to Feast, a ritual-liturgical exploration of reconciliation in South Africa Cultural contexts based on DTh Thesis: Van Vas tot Fees, 'n Ritueelliturgiese ondersoek na Versoek na Versoening binne Suid-Afrikaanse Kultuurkontekste (2004), Stellenbosch University.

Wepener, Ignatius Swart, Gerrie ter Haar, Marcel Barnard, 'The Role of Religious Ritual in Social capital Formation for Poverty Alleviation and Social Capital Development: Theoretical and Methodological Points of Departure of a South African Exploration in progress' (Draft paper used for a conference).

West, M 1975. Bishops and Prophets in a Black City. Cape Town: David Philips.

Woods, R 2010. Article entitled: 'Religious Symbols and Spiritualiy in an Electronic Age' http://www.jstor.org/pss/1199815, p. 2. Accessed 10 November 2010. 